\title{
Overexpression of Human Insulin-Like Growth Factor Binding Protein-1 in the Mouse Leads to Nephron Deficit
}

\author{
SOPHIE DOUBLIER, KAOUTHAR AMRI, DANIELLE SEURIN, EVELYNE MOREAU, \\ CLAUDIE MERLET-BENICHOU, GARY E. STRIKER, AND THIERRY GILBERT \\ INSERM U489, Hôpital Tenon, 75020 Paris, France [S.D.]; INSERM U319, Université Paris 7-Denis \\ Diderot, 75005 Paris, France [K.A., E.M., C.M.-B., T.G.]; INSERM U515, Hôpital Saint-Antoine, 75012 \\ Paris, France [D.S.]; and University of Miami, Laboratory of Renal Cell Biology, \\ Miami, Florida 33101, U.S.A. [G.E.S.]
}

\begin{abstract}
ABSTR
IGFs and their binding proteins are important regulators of
fetal development. We have previously reported that overexpres-
sion of the human IGF binding protein-1 in mice is associated
with glomerulosclerosis. The aim of this study was to investigate
whether, in that model, decreased bioavailability of IGFs also
affected nephrogenesis. When the mothers expressed human IGF
binding protein-1, pups were growth retarded and had a reduced
number of nephrons. Even nontransgenic pups born to heterozy-
gous mothers had a nephron reduction, indicating that renal
hypoplasia was secondary to fetal growth retardation. When the
transgene was expressed only in the fetus, pups had a normal
birth weight and the kidney was normal at birth, as indicated by
histologic studies. However, a significant reduction in the
\end{abstract}
In the mammalian embryo, metanephros formation is initiated when the ureteric bud interacts with the undifferentiated metanephric blastema. This leads to branching morphogenesis of the ureteric bud that subsequently matures into collecting tubules, while groups of mesenchymal cells aggregate on induction by the ureteric bud ends, then become polarized and differentiate into a complete nephron (1). The growth factors involved in the control of the number of nephrons have not been clearly delineated despite the fact that many are expressed within the developing kidney from the early stages of renal organogenesis (2). For example, epidermal growth factor has been shown to modulate the fate of the nephrogenic mesenchyme but toward a stromal cell phenotype (3). And the fibroblast growth factors, which favor the development of renal progenitor cells by rescuing them from apoptosis, do not

Received March 9, 2000; accepted September 25, 2000.

Correspondence and reprint requests: Thierry Gilbert, Ph.D., INSERM U319, Université Paris 7-Denis Diderot, 2 place Jussieu, Tour 33-43, case 7126, 75251 Paris Cedex 05, France; e-mail: TGilbert@Paris7.jussieu.fr

Supported by the Institut National de la Santé et de la Recherche Médicale. SD was recipient of a French fellowship by the Ministère de l'Education Nationale, de l’Enseignement Supérieur et de la Recherche (\#96166). nephron number was observed at 3 mo of age. Because nephrogenesis continues for a few days after birth in the mouse, this indicated that human IGF binding protein-1 overexpression altered postnatal nephrogenesis. In addition, exogenously added IGF-II, but not IGF-I, was effective in stimulating in vitro nephrogenesis. Together these elements suggest that reduced amounts of circulating IGFs, presumably IGF-II, impair kidney development. (Pediatr Res 49: 660-666, 2001)
Abbreviations:
IGFBP, IGF binding protein
hIGFBP-1, human IGF binding protein-1

stimulate mesenchymal-epithelial conversion (4). Only vitamin A derivatives have been shown to modulate the nephron mass in a dose-dependent manner (5-7). Their effects were secondary to an enhanced branching morphogenesis of the ureteric bud, leading more ureteric bud extremities to induce mesenchymal cells to aggregate into nephron anlagen.

The IGF signaling system is a major determinant of mammalian embryonic growth. It depends on the IGF peptides, their binding proteins, and their receptors. IGF peptides and the type 1 IGF receptor are critical to fetal growth and development as shown by the fact that null mutations of IGF-I, IGF-II, and type $1 \mathrm{IGF}$ receptor result in major abnormalities $(8,9)$. To mediate their mitogenic and differentiating effects, IGFs have to be available for their receptors, mainly through the type 1 IGF receptor. Six distinct IGFBPs (IGFBP-1 to -6) have been characterized (10). Three are expressed in the fetal mouse kidney: IGFBP-2, -4, and -5, and they are present from d 14 of gestation (11). IGFs are present in the developing kidneys from embryonic d 13 in the rat (12). Their involvement in renal organogenesis has been further suggested in vitro by blocking metanephric growth with antibodies directed against IGFs (12). The relevance of the type 1 IGF receptor in metanephric 
development has also been reported in mouse kidney organ culture (13). Therefore, IGFs are potential candidates to control the number of nephrons. However, no study has been conducted to investigate this point in vivo in normal birth weight animals.

To address this question, we have used a transgenic model in which overexpressing hIGFBP-1 leads to decreased amounts of circulating IGFs. By mating nontransgenic, heterozygous and homozygous mice, we obtained fetal and/or maternal hIGFBP-1 transgenic expression. The impact on kidney development was analyzed by nephron counting and histologic studies.

\section{METHODS}

\section{Animals}

Wild-type B6/CBA mice and transgenic mice carrying the human $\alpha 1$-antitrypsin promoter fused to hIGFBP-1 cDNA were used in this study, and this promoter was selected to obtain liver-specific expression of the transgene (14). Hepatic expression of the transgene was detected from embryonic d 15. Heterozygous and homozygous transgenic animals and nontransgenic littermates were identified on the basis of Southern blot analysis of DNA samples from tail biopsies; they expressed $3.0 \pm 0.4 \mathrm{ng}$ and $13.7 \pm 1.4 \mathrm{ng}$ of hIGFBP-1 per milliliter, respectively (14).

To investigate the effect of the transgene on renal organogenesis, three types of mating were performed. Animals from mating $\mathrm{B} 6 / \mathrm{CBA}$ female mice with $\mathrm{B} 6 / \mathrm{CBA}$ male mice were controls (group 1). Mating of B6/CBA female mice with homozygous male mice generated newborn mice that were all heterozygous for the transgene (group 2). Animals from mating heterozygous female mice with heterozygous male mice were nontransgenic (group 3), heterozygous (group 4), or homozygous littermates (group 5). To summarize, the newborn mice were distributed as following:

\begin{tabular}{llllll}
\hline & Group 1 & \multicolumn{1}{c}{ Group 2 } & \multicolumn{1}{c}{ Group 3 } & \multicolumn{1}{c}{ Group 4 } & \multicolumn{1}{c}{ Group 5 } \\
\hline Male & B6/CBA & Homozygous & Heterozygous & Heterozygous & Heterozygous \\
Female & B6/CBA & B6/CBA & Heterozygous & Heterozygous & Heterozygous \\
Newborn & B6/CBA & Heterozygous & Nontransgenic & Heterozygous & Homozygous \\
\hline
\end{tabular}

All the female mice were allowed to deliver spontaneously. Newborn animals were weighed within $4 \mathrm{~h}$ of birth. They were killed at birth or at 3 mo of age for histology and nephron mass determination. Kidneys were removed and weighed after sodium pentobarbital anesthesia $(0.6 \mathrm{mg} / 10 \mathrm{~g}$ body wt i.p.).

All protocols used were approved by institutional review committees.

\section{Nephron Mass Determination}

The total number of nephrons was determined in 3-mo-old animals. Eight to 12 animals were used in each group. Whole kidneys were incubated in 50\% hydrochloric acid $(6 \mathrm{~N})$ for 45 to $60 \mathrm{~min}$ at $37^{\circ} \mathrm{C}$ according to the kidney weight. After overnight storage in water at $4^{\circ} \mathrm{C}$, macerated kidneys were placed in $50-\mathrm{mL}$ gauged flasks. Controlled shaking led to a suspension of long tubular structures and intact glomeruli. Two to four aliquots of $0.5 \mathrm{~mL}$ were pipetted and used for glomeruli counting without prior knowledge of the group involved and by two different investigators.

\section{Renal Histology}

Light microscopy. Newborn mice kidneys were fixed with $2.5 \%$ glutaraldehyde in $0.1 \mathrm{M}$ cacodylate buffer $(\mathrm{pH} 7.4)$ and washed overnight in the same buffer. After postfixation in $1 \%$ osmium tetroxide, they were dehydrated through a series of graded ethanol, infiltrated, and flat embedded in Epon. Serial sections of $1 \mu \mathrm{m}$ thick were cut parallel to the short axis of the kidney. Toluidine blue-stained sections were examined with a Nikon Optiphot microscope (Nikon France S.A., Champigny Sur-Marne, France).

Morphologic studies. The number of glomeruli and Sshaped bodies was determined in one whole kidney crosssection of newborn mice. For histologic variable measurements, video images were transferred onto a PowerMac (Apple Computer, Cupertino, CA, U.S.A.) workstation and analyzed using National Institutes of Health Image software (Bethesda, MD, U.S.A.). The position of S-shaped bodies and glomeruli within the cortical layer was recorded. For each group, 150 to 250 measurements were collected within the central zone of the immature cortex, opposite the developing papilla.

\section{Metanephros Organ Culture}

Metanephros organ culture was performed as previously described $(15,16)$. Fetuses from Sprague-Dawley female rats with a known mating date ( $\mathrm{d} 0$ of pregnancy was the day after overnight mating) were taken at embryonic d 14. Whole metanephroi were collected and freed of exogenous tissue. Kidney rudiments were placed onto a $0.8-\mu \mathrm{m}$ Millipore AA filter (Millipore, Saint-Quentin-en-Yvelines, France), floating on a defined serum-free medium, and incubated $6 \mathrm{~d}$ in $35-\mathrm{mm}$ Petri dishes at $37 \pm 0.5^{\circ} \mathrm{C}$ in a humidified incubator $\left(5 \% \mathrm{CO}_{2}\right)$. The medium originally described by Avner et al. (16) was used without insulin. Culture medium was devoid of antibiotic and fungicide and was changed daily. Experiments were performed under paired conditions, i.e. one metanephros was grown as a control, and the contralateral embryonic kidney from the same fetus was grown in IGF-supplemented medium. Human recombinant IGF-I and IGF-II were purchased from R\&D Systems (Oxon, UK) and used at 10, 100, or $1000 \mathrm{ng} / \mathrm{mL}$. All tissue culture reagents were obtained from Sigma Chemical Co., Saint Quentin Fallavier, France.

In vitro renal differentiation was assessed by lectin histochemistry as described previously (15). Briefly, metanephroi were fixed with $2 \%$ paraformaldehyde in PBS, permeabilized with saponin, treated with neuraminidase, and incubated with rhodamine-coupled Arachis Hypogaea agglutinin to label podocyte membranes. The total number of nephrons present within the cultured metanephroi was then determined.

\section{Statistical Analysis}

Data are reported as means with their standard errors. Comparisons of in vivo data between groups were performed by 
ANOVA combined with a test of Tukey. Comparisons of data from in vitro experiments were performed using the Wilcoxon's paired test. Significance was determined by $p<0.05$.

\section{RESULTS}

Maternal or fetal expression of the transgene and pregnancy outcomes. The delivery of most of the female mice occurred during daylight, allowing us to determine and compare the duration of gestation after each mating (Table 1). When B6/CBA female mice were mated with homozygous male mice, the duration of pregnancy was similar to that observed in the control group. A significant reduction of the number of pups per litter was noted, as previously found (14). When heterozygous female mice were mated with heterozygous male mice, the duration of the gestation was significantly longer as compared with the control mating. As observed when B6/CBA female mice were mated with homozygous male mice, the number of pups per litter was significantly reduced, but this reduction was not accompanied by an increased birth weight. As shown in Table 2, the body weight of the pups, irrespective of their genotype (nontransgenic, heterozygous, or homozygous, corresponding to groups 3,4 , and 5 , respectively), was significantly lower as compared with control newborn mice.

Total number of nephrons in transgenic mice. At 3 mo of age, all animals from groups 1 through 4 had a similar body weight $(24.0 \pm 0.6 \mathrm{~g}, 24.0 \pm 1.8 \mathrm{~g}, 24.0 \pm 1.1 \mathrm{~g}$, and $23.0 \pm$ $0.9 \mathrm{~g}$, respectively), but the homozygous transgenic mice (group 5) had a significantly lower body weight $(18.0 \pm 2.0 \mathrm{~g}$; $p<0.001)$. Similarly, kidney weights were significantly lower in homozygous transgenic mice than in mice of groups 1 through $4(0.14 \pm 0.02 \mathrm{~g}$ versus $0.23 \pm 0.09 \mathrm{~g}, 0.25 \pm 0.09 \mathrm{~g}$, $0.22 \pm 0.24 \mathrm{~g}$, and $0.24 \pm 0.11 \mathrm{~g}$, respectively; $p<0.001$ ). Consequently, kidney weight to body weight ratio did not differ among the five groups of mice. This is consistent with our previous findings (14). To evaluate the effect of hIGFBP-1 overexpression on kidney development, we then determined the total number of nephrons in mice of 3 mo of age, when renal differentiation and maturation are completed. Figure 1 reports the total number of nephrons in each group. Heterozygous mice born from a wild-type B6/CBA mother (group 2), corresponding to the expression of the transgene in the fetuses only, had a total number of nephrons reduced by $15 \%$ to $20 \%$ as compared with the wild-type B6/CBA control mice. Nontransgenic (group 3), heterozygous (group 4), and homozygous (group 5) mice born from heterozygous mothers had a similar reduction of the total number of nephrons. No further decrease in the nephron number occurred when the transgene was expressed in both fetus and mother. Intrauterine growth retardation in nontransgenic mice born from the same mating also led to a reduction of the total number of nephrons (Fig. 1, group 3).

Expression of the transgene and renal morphology at birth. To determine whether the expression of the transgene in the fetus only (group 2), in the mother only (group 3), or in both (groups 4 and 5) had an effect on renal development at birth, the morphology of newborn mice kidneys was analyzed. When the transgene was expressed only in the fetus, intrauterine growth was not affected, as showed by normal body weight and kidney weight in group 2 of newborn mice as compared with group 1 (Table 2). Cortical width was similar in groups 1 and 2 , as was the superficial cortical layer containing the nephrogenic mesenchyme and the renal vesicles. When heterozygous females and males were mated, this always resulted in fetal growth retardation. Even the nontransgenic pups (group 3 ) were significantly smaller than the control pups (group 1). Body weight at birth was reduced by about $20 \%$ in all groups of mice, and the same applied for the kidney weight. Both the whole cortical width and the superficial layer of nephrogenic mesenchyme were significantly smaller in groups 3,4 , and 5 than in group 1 (Table 2).

Table 1. Effects of overexpression of hIGFBP-1 on duration of gestation and the mean number of newborns per litter

\begin{tabular}{|c|c|c|}
\hline Mating (female $\times$ male) & $\begin{array}{l}\text { Duration of gestation } \\
\text { (h) }\end{array}$ & $\begin{array}{c}\text { Number of offspring } \\
\text { per litter }\end{array}$ \\
\hline $\mathrm{B} 6 / \mathrm{CBA} \times \mathrm{B} 6 / \mathrm{CBA}(n=5)$ & $12.2 \pm 2.9$ & $9.0 \pm 0.8$ \\
\hline B6/CBA $\times$ homozygous $(n=5)$ & $21.6 \pm 8.0$ & $3.8 \pm 1.2 \ddagger$ \\
\hline
\end{tabular}

Values reported are mean number of hours in addition to $18 \mathrm{~d}$.

$\dagger$ and $\ddagger$ indicate $p<0.05$ and $p<0.01$ as compared with controls, respectively.

Table 2. Effect of overexpression of hIGFBP-1 on renal morphology in newborn mice

\begin{tabular}{|c|c|c|c|c|c|c|}
\hline Group & $\begin{array}{l}\text { Body weight } \\
\text { (g) }\end{array}$ & $\begin{array}{l}\text { Kidney weight } \\
\text { (mg) }\end{array}$ & $\begin{array}{l}\text { Cortical width } \\
\qquad(\mu \mathrm{m})\end{array}$ & $\begin{array}{l}\text { Nephrogenic } \\
\text { zone width } \\
\quad(\mu \mathrm{m})\end{array}$ & $\begin{array}{l}\text { Glomeruli per } \\
\text { cross-section }\end{array}$ & $\begin{array}{l}\text { S-shaped bodies } \\
\text { per cross-section }\end{array}$ \\
\hline $1(n=9)$ & $1.52 \pm 0.08$ & $8.6 \pm 0.9$ & $347 \pm 20$ & $78 \pm 9$ & $39.6 \pm 1.2$ & $32.2 \pm 1.3$ \\
\hline $3(n=3)$ & $1.32 \pm 0.08^{*}$ & $6.6 \pm 1.5$ & $317 \pm 15^{*}$ & $60 \pm 15^{*}$ & $32.0 \pm 3,5^{*}$ & $23.0 \pm 1.2^{*}$ \\
\hline $4(n=9)$ & $1.34 \pm 0.03 *$ & $6.5 \pm 0.4^{*}$ & $318 \pm 24^{*}$ & $65 \pm 7 *$ & $34.3 \pm 1.1^{*}$ & $22.8 \pm 1.5^{*}$ \\
\hline $5(n=4)$ & $1.19 \pm 0.05^{*}$ & $6.1 \pm 0.6^{*}$ & $310 \pm 16^{*}$ & $69 \pm 8 *$ & $29.0 \pm 2.0^{*}$ & $22.8 \pm 3.3^{*}$ \\
\hline
\end{tabular}

Newborn rats from mating B6/CBA female mice with B6/CBA male mice were controls (group 1). Mating of B6/CBA female mice with homozygous male mice generated newborn mice that were all heterozygous for the transgene (group 2). Animals from mating heterozygous female mice with heterozygous male mice were nontransgenic (group 3), heterozygous (group 4), or homozygous littermates (group 5).

$* p<0.05$ as compared with group 1 . 
Number of nephrons

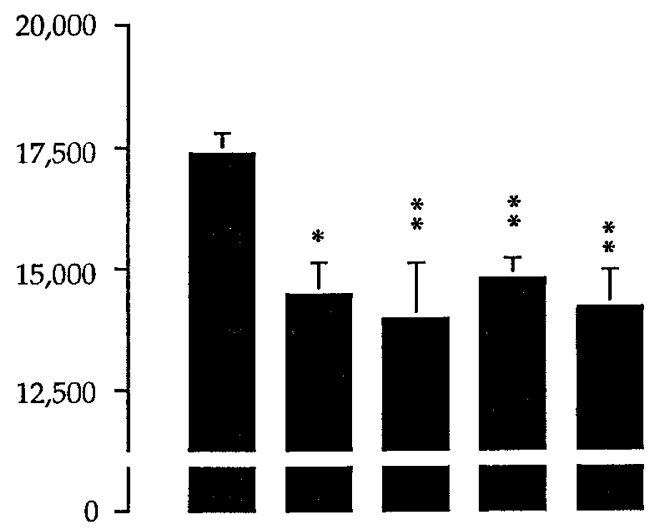

$\begin{array}{rccccc}\text { Maternal hIGFBP1 } & - & - & + & + & + \\ \text { IUGR } & - & - & + & + & + \\ \text { Fetal hIGFBP1 } & - & + & - & + & ++ \\ \text { Group } & 1 & 2 & 3 & 4 & 5\end{array}$

Fig. 1. Overexpression of hIGFBP-1 and nephrogenesis. The total number of nephrons was determined in 3-mo-old pups issued from mating B6/CBA $\times$ B6/CBA (group 1), B6/CBA $\times$ homozygous (group 2), or heterozygous $\times$ heterozygous (groups 3, 4, and 5). Expression of maternal and fetal hIGFBP-1 is reported for every group. Occurrence of intrauterine growth retardation $(I U G R)$ is indicated. All animals display a significant nephron mass reduction. * and ** indicate $p<0.05$ and 0.01 , respectively, compared with group 1 .

To determine when the nephron deficit took place in mice expressing hIGFBP-1 in the absence of growth retardation (group 2), we analyzed in details the renal morphology of newborn mice issued from B6/CBA female mice mated with homozygous male mice. In the mouse, nephrogenesis continues for a few days after birth. Therefore, besides the few developed glomeruli, nephron anlage stages such as S-shaped bodies and immature glomeruli can be identified on crosssections of newborn kidneys. Counting of both glomeruli and $\mathrm{S}$-shaped bodies is reported in Table 2. The same number of glomeruli and S-shaped bodies was found within the renal cortex of newborn mice of groups 1 and 2. Because nephrogenesis proceeds according to a centrifugal pattern, the deep glomeruli within the cortical layer represent the nephrons that have been induced first and the structures close to the renal capsule the ones that have been induced last. By recording the position of S-shaped bodies and glomeruli within the renal cortex, this allows us to analyze the successive generations of nephrons (Fig. 2A). As shown in Figure 2B, the nephron distribution in mice of groups 1 and 2 is also similar. Together, these data indicate that the fetal part of nephrogenesis was not affected in pups expressing hIGFBP-1. In growth retarded mice of groups 3,4 , and 5 , a significant reduction of both the number of glomeruli and of S-shaped bodies was already present at birth.

Effect of IGF-I and IGF-II on renal differentiation in vitro. To discriminate between the potential role of IGF-I or IGF-II on nephron induction, we used metanephros organ culture. Exogenously added IGF-I or IGF-II promoted meta- nephros growth as shown in Figure 3. However, IGF-I had no effect on the number of nephrons formed in vitro whatever the concentration used. In contrast, IGF-II increased the number of nephrons by 25 and $40 \%$ at 100 and $1000 \mathrm{ng} / \mathrm{mL}$, respectively.

\section{DISCUSSION}

The effects of increased IGFBP-1, which decreased the availability of IGFs, were investigated on nephron induction in mice transgenic for hIGFBP-1 (14). The expression of the transgene was liver-specific and permanent from embryonic $\mathrm{d}$ 15 onward. Our results show that overexpression of hIGFBP-1 in the fetus or in the mother affected nephron number. When hIGFBP-1 is expressed only in the fetus, nephrogenesis is not affected before birth. Fetal growth was normal and morphology of the newborn kidney was undistinguishable from that of controls. However, a permanent reduction of approximately $20 \%$ of the number of nephrons is present in all transgenic mice born from a nontransgenic mother. Thus, the reduction in nephron number occurs during postnatal nephrogenesis in these mice. When hIGFBP-1 is expressed in the mother, and whatever genotype the fetuses are (homozygous, heterozygous, or nontransgenic), this results in a significant intrauterine growth retardation in the offspring. The fact that these growthretarded mice displayed a reduced number of nephrons is consistent with the observation of a thinner cortical width and with previous data (17-20). When hIGFBP-1 was expressed in both fetus and mother, there was no additional decrease in the number of nephrons, excluding an additive effect.

IGFBP-1 overexpression might impair kidney development by decreasing IGF bioavailability. Indeed, IGFs are bound to IGFBPs with high affinity $\left(10^{-10}\right.$ to $\left.10^{-11} \mathrm{M}\right)$, and both IGF-I and II have similar affinity for IGFBP-1 (21). Because the affinity of IGFs for the IGFBPs and for the type 1 IGF receptor are similar, they could compete in vivo for ligand binding. Approximately $99 \%$ of IGFs are bound to IGFBP. In the circulation, $80 \%$ of the IGFs are bound to a high molecular weight complex containing IGFBP-3. The remaining $20 \%$ of the IGFs are associated with IGFBP-1, -2 , or -4 in a smaller complex, which can diffuse into the intravascular space, target IGFs to tissues, and modulate their bioavailability by inhibiting or potentiating their actions (21). In the kidney, IGFBPs are heterogeneously distributed to support their modulatory role in IGF actions $(11,22,23)$. The overexpression of hIGFBP-1 in our transgenic mice $(13.7 \pm 1.4 \mathrm{ng} / \mathrm{mL}$ and $3.0 \pm 0.4 \mathrm{ng} / \mathrm{mL}$ in homozygous and heterozygous mice, respectively) remained stable with age (14). This resulted in significant postnatal growth retardation, which may be caused by a decrease in IGF-I bioavailability that may result from both an excess of IGFBP-1 and a lack of IGF-I. Indeed, immunoreactive IGF-I plasma concentrations are decreased by half in homozygous adult transgenic mice compared with nontransgenic littermates (14). Numerous studies of the hepatic secretion of IGFBP-1 show that plasma IGFBP-1 crosses the capillary boundary and controls the bioavailability of free IGF in the tissues $(24,25)$. When IGFBP-1 plasma levels are high, as consistently seen in malnutrition, IGF bioavailability is reduced $(24,25)$.

Nephron deficit in transgenic mice born to a nontransgenic mother (group 2) would not result from intrauterine growth 
A

B

Nephron population (\%)
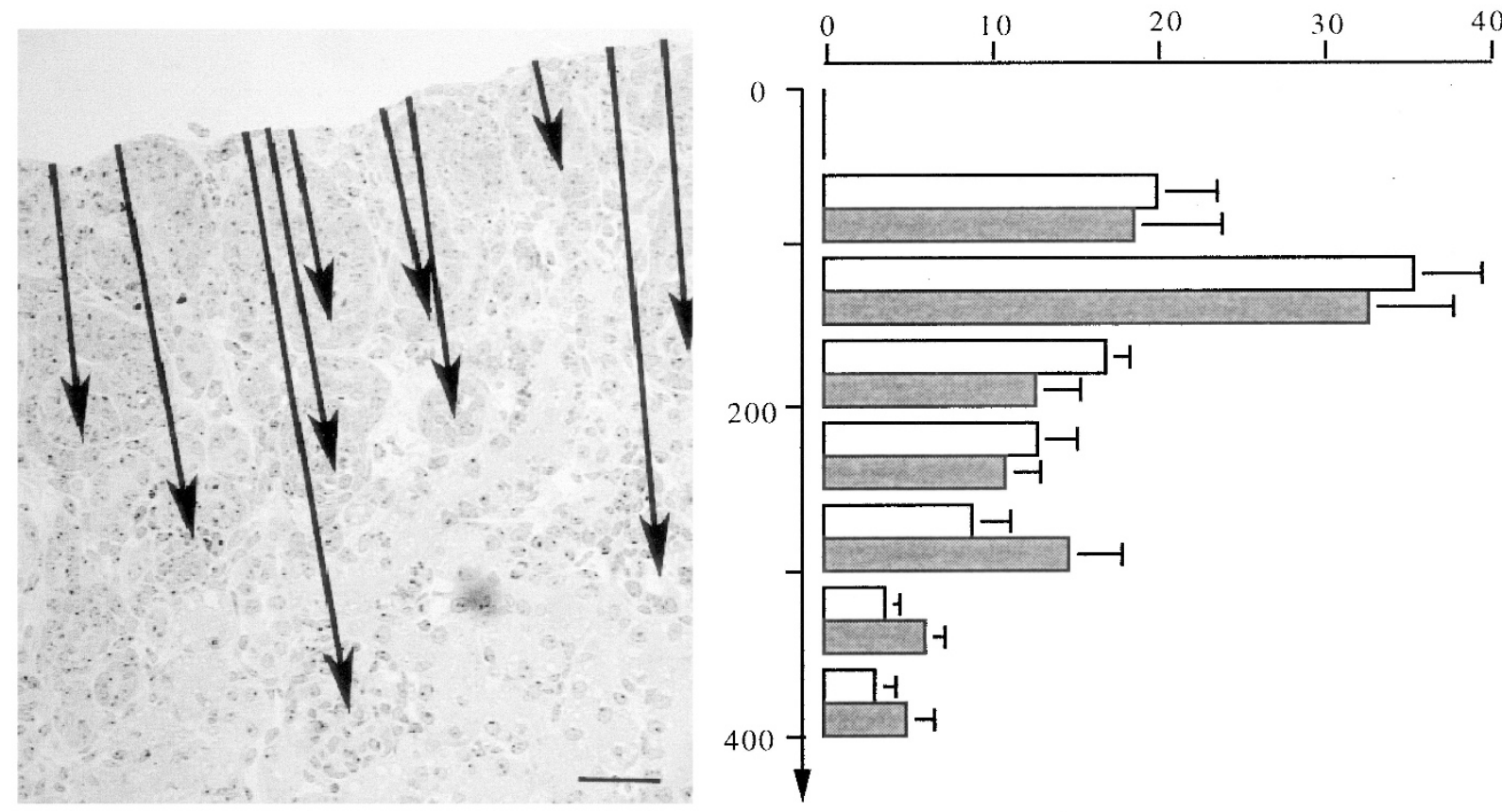

Cortical depth $(\mu \mathrm{m})$

Fig. 2. Nephron distribution in newborn mice. On semithin sections of newborn mouse kidney, positions of S-shaped bodies and immature glomeruli were recorded by measuring their distance from the renal capsule $(A$, arrows). Distribution of the successive generations of nephrons is illustrated in $B$. Nephron positions were recorded and analyzed in eight successive layers of $50 \mu \mathrm{m}$ thickness each. In group 1 (control, open bars) and group 2 (fetal expression of the transgene, closed bars), a similar exponential nephrogenesis occurred. The nephrons detected within the 50- to 150- $\mu \mathrm{m}$ layers correspond to S-shaped bodies. No nephron anlage is found in the most superficial cortical layer, as expected. Bar represents $50 \mu \mathrm{m}$.

retardation and would occur during postnatal nephrogenesis (no more nephron induction on postnatal d 3 in the mouse). hIGFBP-1 is constantly expressed in the transgenic animals between embryonic d 19 and postnatal d 90 (14). Therefore, it could affect the last stages of kidney development by inhibiting the action of IGF. It has to be noted that between embryonic $\mathrm{d}$ 19 and postnatal d 1, despite a similar expression of the transgene, a significant increase in the binding affinity of IGFBP-1 was observed (14) suggesting that the bioavailability of circulating and local IGFs was probably restricted after birth in IGFBP-1 mice. This may account for the regulation of the final stages of renal organogenesis. As already described in rodents, levels of circulating IGF-I considerably increased after birth, whereas circulating IGF-II levels decrease (26). In the developing mouse kidney, IGF-II mRNA levels are high and peak after birth (11). Reexamination of IGF-I null mice has recently shown that a $20 \%$ nephron deficit was observed in the few surviving mice (27). However, those mice exhibited generalized organ hypoplasia and severe growth retardation at birth. Inasmuch as growth retardation alone results in nephron number reduction, clear conclusions could not be drawn concerning a direct effect of IGF-I on nephrogenesis. In hIGFBP-1 mice, we show that postnatal nephrogenesis is affected, but whether this was caused by a deficit of IGF-I or IGF-II remains to be determined. The previous characterization of this model demonstrated that hIGFBP-1 heterozygous and wild-type mice had similar plasma IGF-I concentrations. As evidenced in vitro for early stages of nephrogenesis, IGF-II but not IGF-I can increase the number of nephrons in a dose-dependent manner. This suggests that, in group 2, the defect in postnatal nephron induction is rather secondary to a significant decrease of circulating IGF-II. Throughout kidney development, IGF-II is expressed at high levels compared with IGF-I, and this holds true during the first postnatal days when most of the nephrons are formed $(11,22)$. However, we cannot exclude that increased amount of IGFBP-1 may have its own effect on renal organogenesis; it has been shown that IGFBP-1 through its RGD (Arg-Gly-ASP) sequence can interfere with integrin signaling $(28,29)$, known to play a role during kidney development (30-32).

The nephron deficit in mice born from transgenic mothers may be related to fetal growth retardation. Fetal growth retardation caused by a restriction of maternal food or protein or by partial uterine artery ligation leads to small fetal kidneys (19, $33,34)$. Examination of kidney sections taken from newborn rats issued from protein-deprived mothers suggested that the small kidney size was associated with the reduced nephron number (20). Determination of the total number of nephrons confirmed that there was a direct correlation between growth retardation and a reduction in nephron number (19). Recent experiments have shown that high doses of dexamethasone given to pregnant rats from $\mathrm{d} 1$ after mating to parturition affect 

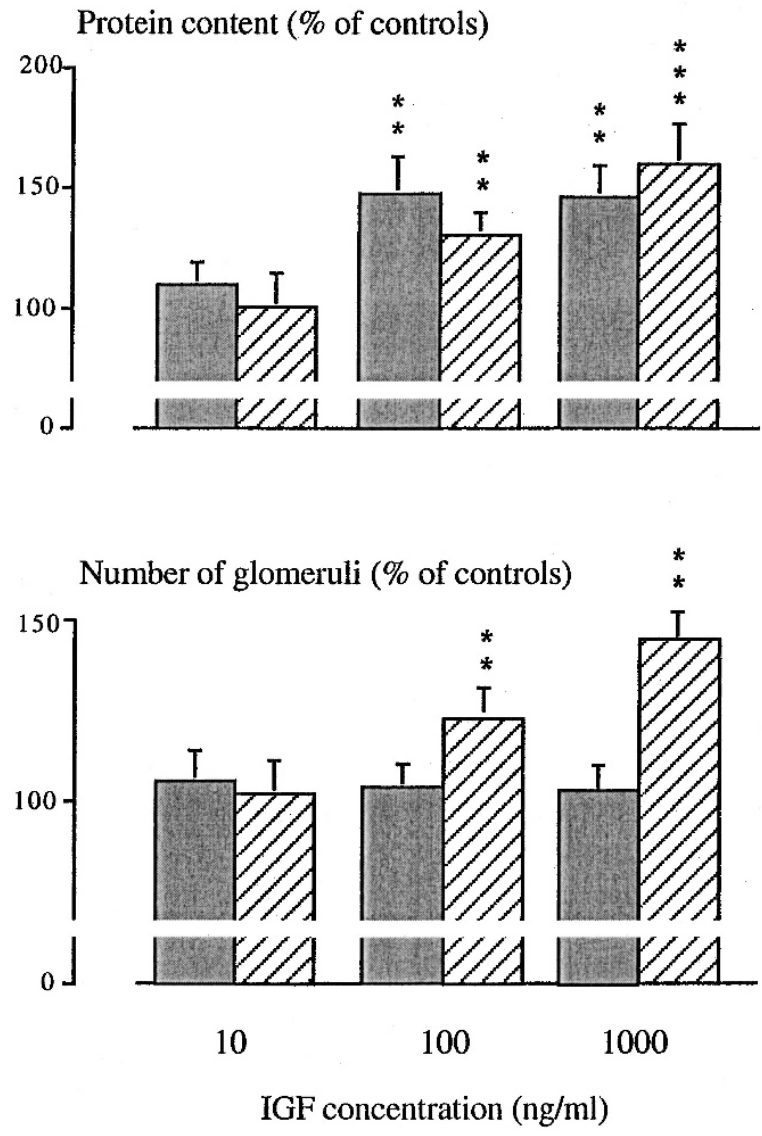

Fig. 3. IGFs and in vitro renal development. Pairs of metanephroi from 14-d-old rat embryos were grown for $6 \mathrm{~d}$ in a serum- and insulin-free medium with or without IGF-I (gray bars) or -II (hatched bars) at 10, 100, or 1000 $\mathrm{ng} / \mathrm{mL}$. Growth and differentiation were assessed by protein content and glomeruli counting, respectively. Both IGFs promote metanephros growth. However, only IGF-II is able to promote significantly kidney differentiation in vitro. ${ }^{* *}$ and $* * *$ indicate $p<0.01$ and 0.001 , respectively, compared with paired controls.

nephrogenesis, leading to substantial nephron deficits (35). The pups have a reduced birth weight, which may per se result in nephron deficit. The same relationship exists in man: intrauterine growth retardation may be a major cause of inborn nephron deficit $(17,18,36)$, pointing to the possible involvement of common growth factors responsible for fetal development and determination of the number of renal functional units. It is well known that intrauterine growth retardation in animal models and in man is associated with an increased IGFBP-1 expression during the fetal period $(24,25)$. There is an inverse relationship between birth weight and both fetal and maternal serum IGFBP-1 (37-40). These studies on IGFBP-1 in relation to birth weight were performed on samples collected at or close to the time of delivery. Hills et al. (41) recently studied this relationship throughout pregnancy. They showed that maternal serum IGFBP-1 levels are high and low in small-forgestational-age and large-for-gestational-age babies, respectively, as compared with average-for-gestational-weight babies. This suggests that IGFBP-1 may be an important factor in pathologic growth retardation. Because IGFBP-1 does not cross the placenta (42), fetal growth retardation in groups from hIGFBP-1 transgenic mothers is probably secondary to insuf- ficient nutrient supply. This is consistent with the proposal that high IGFBP-1 levels could limit placental growth with a secondary effect on fetal growth (41).

In conclusion, we provided evidence, in vivo, that overexpression of IGFBP-1 can affect renal organogenesis without the occurrence of intrauterine growth retardation. The reduction in nephron number is likely related to a decreased bioavailability of IGFs. Experiments are needed to further discriminate between the role of IGF-I and IGF-II on in vivo nephrogenesis.

Acknowledgment. The authors thank L Baud, M Binoux, and LJ Striker for critically reading the manuscript.

\section{REFERENCES}

1. Saxén L 1987 Organogenesis of the Kidney. Developmental and Cell Biology Series. Cambridge University Press, Cambridge, pp 1-34

2. Merlet-Bénichou C, Vilar J, Lelièvre-Pégorier M, Moreau E, Gilbert T 1997 Fetal nephron mass: its control and its deficit. In: Grünfeld JP, Bach JF, Kreis H (eds) Advances in Nephrology. Mosby-Year Book, St. Louis, pp 20-45

3. Weller A, Sorokin L, Illgen EM, Ekblom P 1991 Development and growth of mouse embryonic kidney in organ culture and modulation of development by soluble growth factor. Dev Biol 144:248-261

4. Barasch J, Qiao J, McWilliams G, Chen D, Oliver J, Herzlinger D 1997 Ureteric bud cells secrete multiple factors, including bFGF, which rescue renal progenitors from apoptosis. Am J Physiol 273:F757-F767

5. Vilar J, Gilbert T, Moreau E, Merlet-Benichou C 1996 Metanephros organogenesis is highly stimulated by vitamin A derivatives in organ culture. Kidney Int 49:14781487

6. Moreau E, Vilar J, Lelievre-Pegorier M, Merlet-Benichou C, Gilbert T 1998 Regulation of c-ret expression by retinoic acid in rat metanephros: implication in nephron mass control. Am J Physiol 275:F938-F945

7. Merlet-Benichou C, Vilar J, Lelievre-Pegorier M, Gilbert T 1999 Role of retinoids in renal development: pathophysiological implication. Curr Opin Nephrol Hypertens $8: 39-43$

8. De Chiara T, Efstratiatis A, Robertson E 1990 A growth deficiency phenotype in heterozygous mice carrying an insulin-like growth factor II gene disrupted by targeting. Nature 345:78-80

9. Liu JP, Baker J, Perkins AS, Robertson EJ, Efstratiadis A 1993 Mice carrying null mutations of the genes encoding insulin-like growth factor I (Igf-1) and type 1 IGF receptor (Igf1r). Cell 75:59-72

10. Murphy L, Barron D 1993 The IGFs and their binding proteins in murine development. Mol Reprod Dev 35:376-381

11. Lindenbergh-Kortleve D, Rosato R, Van Neck J, Nauta J, Van Kleffens M, Groffen C, Zwarthoff E, Drop S 1997 Gene expression of the insulin-like growth factor system during mouse kidney development. Mol Cell Endocrinol 132:81-91

12. Rogers SA, Ryan G, Hammerman MR 1991 Insulin-like growth factors I and II are produced in the metanephros and are required for growth and development in vitro. J Cell Biol 113:1447-1453

13. Liu ZZ, Wada J, Alvares K, Kumar A, Wallner EI, Kanwar YS 1993 Distribution and relevance of insulin-like growth factor-I receptor in metanephric development. Kidney Int 44:1242-1250

14. Gay E, Seurin D, Babajko S, Doublier S, Cazillis M, Binoux M 1997 Liver-specific expression of human insulin-like growth factor binding protein-1 in transgenic mice: repercussions on reproduction, ante- and perinatal mortality and postnatal growth. Endocrinology 138:2937-2947

15. Gilbert T, Gaonach S, Moreau E, Merlet-Bénichou C 1994 Defect of nephrogenesis by gentamicin in rat metanephric organ culture. Lab Invest 70:656-666

16. Avner ED, Ellis D, Temple T, Jaffe R 1982 Metanephric development in serum free organ culture. In Vitro Cell Dev Biol 18:675-682

17. Hinchliffe SA, Lynch MR, Sargent PH, Howard CV, Van Velzen D 1992 The effect of intrauterine growth retardation on the development of renal nephrons. Br J Obstet Gynaecol 99:296-301

18. Konje JC, Bell SC, Morton JJ, de Chazal R, Taylor DJ 1996 Human fetal kidney morphometry during gestation and the relationship between weight, kidney morphometry and plasma active renin concentration at birth. Clin Sci 91:169-175

19. Merlet-Benichou C, Gilbert T, Muffat-Joly M, Lelievre-Pegorier M, Leroy B 1994 Intrauterine growth retardation leads to a permanent nephron deficit in the rat. Pediatr Nephrol 8:175-180

20. Zeman FJ 1968 Effects of maternal protein restriction on the kidney of the newborn young of rats. J Nutr 94:111-116

21. Clemmons DR 1997 Insulin-like growth factor binding proteins and their role in controlling IGF actions. Cytokine Growth Factor Rev 8:45-62

22. Matsell D, Delhanty P, Stepaniuk O, Goodyear C, Han V 1994 Expression of insulin-like growth factor and binding protein genes during nephrogenesis. Kidney Int 46:1031-1042

23. Price G, Berka J, Edmondson S, Werther G, Bach L 1995 Localization of mRNAs for insulin-like growth factor binding proteins 1 to 6 in rat kidney. Kidney Int 48:402411 
24. Lassarre C, Hardouin S, Daffos F, Forestier F, Frankenne F, Binoux M 1991 Serum insulin-like growth factors and insulin-like growth factor binding proteins in the human fetus: relationships with growth in normal subjects and in subjects with intrauterine growth retardation. Pediatr Res 29:219-225

25. Unterman T, Lascon R, Gotway MB, Oehler D, Gounis A, Simmons RA, Ogata ES 1990 Circulating levels of insulin-like growth factor binding protein-1 (IGFBP-1) and hepatic mRNA are increased in the small for gestational age (SGA) fetal rat [published erratum appears in Endocrinology 1991;128(1):400]. Endocrinology 127:2035-2047

26. Rotwein P 1991 Structure, evolution, expression and regulation of insulin-like growth factors I and II. Growth Factors 5:3-18

27. Rogers SA, Powell-Braxton L, Hammerman MR 1999 Insulin-like growth factor I regulates renal development in rodents. Dev Genet 24:293-298

28. Meredith Jr JE, Winitz S, Lewis JM, Hess S, Ren XD, Renshaw MW, Schwartz MA 1996 The regulation of growth and intracellular signaling by integrins. Endocr Rev 17:207-220

29. Jones JI, Gockerman A, Busby Jr WH, Wright G, Clemmons DR 1993 Insulin-like growth factor binding protein 1 stimulates cell migration and binds to the alpha 5 beta 1 integrin by means of its Arg-Gly-Asp sequence. Proc Natl Acad Sci U S A 90:10553-10557

30. Muller U, Wang DN, Denda S, Meneses JJ, Pedersen RA, Reichardt LF 1997 Integrin alpha 8 beta 1 is critically important for epithelial-mesenchymal interactions during kidney morphogenesis. Cell 88:603-613

31. Falk M, Salmivirta K, Durbeej M, Larsson E, Ekblom M, Vestweber D, Ekblom P 1996 Integrin a6Bb1 is involved in kidney tubulogenesis in vitro. J Cell Sci 109:2801-2810

32. Kreidberg JA, Donovan MJ, Goldstein SL, Rennke H, Shepherd K, Jones RC, Jaenisch R 1996 Alpha 3 beta 1 integrin has a crucial role in kidney and lung organogenesis. Development 122:3537-3547

33. Minkowski A, Chanez C 1983 Some pathophysiologic changes in experimental intrauterine malnutrition. In: Kretchmer N , Minkowski A (eds) Nutritional Adaptation of Gastrointestinal Tract of the Newborn. Raven Press, New York, pp 131-149
34. Zeman FJ 1967 Effect on the young rat of maternal protein restriction. J Nutr 93:167-173

35. Celsi G, Kistner A, Aizman R, Eklöf A, Ceccatelli S, de Santiago A, Jacobson S 1998 Prenatal dexamethasone causes oligonephronia, sodium retention, and higher blood pressure in the offspring. Pediatr Res 44:317-322

36. Merlet-Benichou C, Gilbert T, Vilar J, Moreau E, Freund N, Lelievre-Pegorier M 1999 Nephron number: variability is the rule: causes and consequences. Lab Invest 79:515-527

37. Hall K, Hansson U, Lundin G, Luthman M, Persson B, Povoa G, Stangenberg M, Ofverholm U 1986 Serum levels of somatomedins and somatomedin-binding protein in pregnant women with type I or gestational diabetes and their infants. J Clin Endocrinol Metab 63:1300-1306

38. Howell RJ, Perry LA, Choglay NS, Bohn H, Chard T 1985 Placental protein 12 (PP12): a new test for the prediction of the small-for-gestational-age infant. $\mathrm{Br} \mathrm{J}$ Obstet Gynaecol 92:1141-1144

39. Wang HS, Lim J, English J, Irvine L, Chard T 1991 The concentration of insulin-like growth factor-I and insulin-like growth factor-binding protein-1 in human umbilical cord serum at delivery: relation to fetal weight. J Endocrinol 129:459-464

40. Verhaeghe J, Van Bree R, Van Herck E, Laureys J, Bouillon R, Van Assche FA 1993 C-peptide, insulin-like growth factors I and II, and insulin-like growth factor binding protein-1 in umbilical cord serum: correlations with birth weight. Am J Obstet Gynecol 169:89-97

41. Hills F, English J, Chard T 1996 Circulating levels of IGF-I and IGF-binding protein-1 throughout pregnancy: relation to birthweight and maternal weight. J Endocrinol 148:303-309

42. Giudice L, Irwin J, Dsupin B, de las Fuentes L, Jin I, Vu T, Hoffman A 1994 Insulin-like growth factors (IGFs), IGF binding proteins (IGFBPs) and IGFBP protease in human uterine endometrium: their potential relevance to endometrial cyclic and maternal-embryonic interactions. In: Baxter RC, Gluckman PD, Roesenfeld RG (eds) The Insulin-Like Growth Factors and Their Regulatory Proteins. Elsevier, New York, pp 351-361 